\title{
Factors affecting macropropagation of bamboo with special reference to culm cuttings: a review update
}

\author{
Syandan Sinha Ray ${ }^{1}$ and Md. Nasim Ali $^{2^{*}}$
}

\begin{abstract}
Background: The gap between demand and supply of bamboo is increasing daily due to the destruction of natural bamboo resources. Therefore, there is a pressing need to find suitable methods for large-scale propagation of bamboo. Currently, bamboo is propagated mainly using vegetative means since seed supplies are often variable or limited.

Methods: Current literature on available methods of bamboo propagation (seed and vegetative) were reviewed to establish the key limiting factors involved in the propagation of bamboo.

Results: The vegetative propagation of bamboo via culm cuttings was found to be the simplest and most cost-effective method developed over the last few decades.

Conclusions: Additional work is required to increase the success rate of culm cuttings, and finding improved substrates for the propagules could be one area of investigation.
\end{abstract}

Keywords: Bamboo, Culm cuttings, Macropropagation, Plant growth regulators, Seasonal effect

\section{Review} Introduction

The demand for bamboo is increasing steadily because of its multipurpose utility (Goyal et al. 2010; Gulabrao et al. 2012). Twenty million hectares of bamboo (equivalent to $80 \%$ of total world stock) are available from India, China and Myanmar (Mishra 2015). In most of these countries, including India, 99\% of bamboo products are supplied from natural forests (Agnihotri and Nandi 2009). China is considered as the largest bamboo resource of the globe, having 500 species in 40 genera (Yuming et al. 2004) distributed in 7.6 million hectares of forest land (Ruíz-Pérez et al. 2004). The current taxonomic authorities for all the species referred to in this review are available from the Plant List (www.theplantlist.org). Phyllostachys edulis (Moso bamboo) is the most economically important bamboo species, but other species, namely Chimonocalamus delicatus, Dendrocalamus membranaceus and Fargesia yunnanens, are prevalent in China (Mera and $\mathrm{Xu}$ 2014). India is considered

\footnotetext{
* Correspondence: nasimali2007@gmail.com

${ }^{2}$ Department of Agricultural Biotechnology, Faculty of Agriculture, Bidhan Chandra KrishiViswavidyalaya, Mohanpur, Nadia 741252, West Bengal, India Full list of author information is available at the end of the article
}

as the second largest bamboo resource in terms of species diversity after China (Yeasmin et al. 2015) and of production (Pathak 1989). In India, 18 genera and 128 species of bamboo have been reported by Seethalakshmi and Kumar (1998), among which 41 species are exotic to India. Bambusa balcooa, Bambusa bambos, Bambusa tulda, Dendrocalamus hamiltonii, and Dendrocalamus strictus are the main economically important bamboo species of India (Yeasmin et al. 2015). In India, according to Yengkopam (2013), 8.96 million hectares of 63.3 million hectares of forest land is covered by bamboo. However, a forest survey of India estimated that 13 million hectares of India's forest land are covered by bamboo growing stock, which yields around 169 million tonnes of 'wood' (Roy et al. 2014). In India, bamboo is also considered as an important economic resource for nearly 7.5 million bamboo artisans (Prabu 2006). The total value of bamboo forest produces is expected to reach USD 48 billion within 2020 in China (Phimmachanh et al. 2015). The economic value of total bamboo harvest in India is USD 0.30 billion (Mahapatra and Shrivastava 2013) and its products have a potential export value amounting to USD 4.46 billion by 2025 (Mehra and Mehra 2007). Human activities such as deforestation, industrialisation, and illegal 
extraction of bamboo, have resulted in the loss of natural bamboo resources (Subramaniam 1998; Roy et al. 2014). Therefore, it is necessary to find cost-effective methods for large-scale propagation of bamboo for planting in new bamboo forests to reduce the existing gap between demand and supply. This review discusses the advantages and disadvantages of seed and various vegetative methods for propagating bamboo and the key factors affecting success.

\section{Seed-based propagation}

Seeding in bamboo is very irregular and unavailable for most of the species (Arya et al. 2002; Ntirugulirwa et al. 2012). Bamboo flowers gregariously or sporadically after long intervals to produce seeds. In gregarious flowering, the entire local populations of the individual species die after flowering (Dwivedi 1988). However, in sporadic flowering, only a minority of culms (the hollow main axes of upright shoots) in clumps produce flowers and die. Sporadic flowering is reported in B. balcooa, $B$. nutans, B. vulgaris and B. longispiculata while gregarious flowering is reported in B. tulda, B. bambos, B. polymorpha, Dendrocalamus longispathus, D. strictus and Oxytenanthera nigrociliata (Banik 1985). Some species do not even produce seed (e.g. Bambusa balcooa, B. vulgaris), and those that do so often flower at long intervals varying from 30 to 70 years (e.g. Bambusa bambos, B. polymorpha, Dendrocalamus strictus, Melocanna baccifea and Phyllostachys spp.). Therefore, availability of seed may only be after long time intervals, seed viability may be poor and brief, storage facilities suitable for seed may be lacking, highly heterogeneous seedling populations may occur, and often overall poor seed set and consumption of seed by wild animals are the major problems with seed-based propagation (Singh et al. 2013). Seed-based propagation methods, therefore, cannot be relied for mass multiplication on a sustainable basis, so there is strong need to explore the possibility of vegetative propagation for mass multiplication of bamboo.

\section{Vegetative propagation}

The potential advantage of vegetative propagation is the production of true-to-type plants on a sustainable basis, which is clearly not feasible with seeds. However, plants raised through vegetative propagation maintain a definite vegetative time period before flowering, due to the physiological age of the mother plant. There is a danger that flowering, and death, could occur soon after propagation (Banik 1985). Therefore, before collecting the propagating material, plant age and relevant physiological details need to be ascertained for each species, noting that there may be environmental effects which can change this status. Relevant establishment records for the mother plants must be developed and maintained. Widely used vegetative propagation methods for bamboo are rhizome or offset cuttings, layering and culm cuttings (Gaur 1985).

A brief account on the different methods of vegetative propagation is discussed here under the following subheadings.

Macroproliferation Bamboo seedlings possess the capacity to proliferate. In this method, the rhizome system of a seedling is cut into pieces, each with roots and shoots. Then each piece with a shoot and root is used as propagating material (Banik 1995). By this method, each plant can be multiplied three to seven times, depending on the species. However, seed dependency is the major drawback of this method (Razvi et al. 2011).

'Rhizome' - or 'offset'-based propagation 'Offsets' or 'rhizomes' are conventionally used for propagating the sympodial bamboos. In this method, either whole rhizomes or portions each with single culm having three to five basal nodes (called offsets) are used as propagating material. Offsets, however, are difficult to handle and transport because of their bulkiness, and are not cost-effective due to limited availability and a low regeneration capacity, i.e. slow growth and/or poor multiplication rates. They are also prone to desiccation, are labour intensive, season dependent and have a low survival rate, and therefore are unsuitable for large-scale plantations (Islam et al. 2011; Razvi et al. 2011, Mudoi et al. 2013, Singh et al. 2013).

Layering In this method either a whole culm or a branch bearing part of the culm is bent down to the ground so that the nodes are pegged into the soil. Roots develop from the nodal regions are separated and planted in polybags for hardening (Seethalakshmi and Kumar 1998). Different types of layering include:

a) Ground layering, where a culm is bent down to ground and covered with rooting medium.

b) Air layering/marcotting, in which the root-promoting medium (garden soil, leaf mould and commercial plant growth regulators, etc.) is applied around the nodes of the culm and often wrapped longitudinally with coconut fibre and/or water hyacinth roots (Ahlawat et al. 2002).

c) Stump layering, one to two node stumps of severed culms are covered with a suitable propagating medium. The low success rate of this layering method limits its use. Through stump layering, only $10 \%$ survival has been reported in B. vulgaris and D. giganteus (Banik 1984; Serajuddoula 1985). This method is also difficult to follow if clumps of bamboo are tightly bunched or culms have thin walls (Banik 1995) which limits its application for other species. 
Cutting-based propagation Vegetative propagation using 'cuttings' has advantages over 'rhizome'/'offsets' (Ntirugulirwa et al. 2012). Cutting-based propagation does not damage the mother plant and cuttings are also easily available for large-scale propagation. This could be achieved by either 'branch cuttings' or 'culm cuttings'.

a) Branch cuttings

The primary branches are easily separated from the hollow main stem of an upright shoot (culm) and reduced to two- to three-node cuttings and buried in growth medium. The basic advantages of branch cuttings are abundant availability and ease of handling (Razvi et al. 2011). However, the method is restricted to thick-walled bamboo species only (Bareja 2010). Branch cuttings require 6-12 months for rooting and 1230 months for rhizome development and thus are timeconsuming to produce (Banik 1995) indicating that plants produced by this method have slower growth.

b) Culm cuttings

In this method, the culm segments with two-three nodes from the mother plants are taken to propagate bamboo species (Bareja 2010). This method is applicable for both thick- and thin-walled bamboo, but the success rate is quite low in thin-walled bamboo. Rooting can be possible within 90 days of setting of cuttings in rooting media (Banik 1995).

The lack of success of vegetative propagation methods mentioned earlier (macroproliferation, 'rhizome'- or 'offset'-based propagation and layering-based propagation) other than cuttings is notorious. It is evident from the literature that culm/branch cuttings are suitable for propagation because of easy handling and abundant availability (McClure 1966, Pattanaik et al. 2004). Ahlawat et al. (2002) reported that culm cuttings are $40-80 \%$ more successful than the offset method. The chief advantage of culm cuttings is that they can be collected from the stock material without affecting the rhizome system (Stapleton 1985). Besides wider applicability, culm cuttings are advantageous in circumventing the limitations (discussed earlier) of branch cuttings. Culm cuttings were found to be better than branch cuttings; in terms of rooting, $88.3 \%$ rooting in culm cuttings was observed which was more than double in comparison to that in branch cuttings (40\%) in B. nutans, while in B. tulda it was $23.3 \%$, compared with no rooting in branch cutting material (Singh et al. 2011). Culm cuttings have performed better with respect to rooting response percentage ( $70.6 \%)$, number of roots/node ( 15.3) and number of shoots/node $(\sim 9.4)$, than branch cuttings which showed $\sim 60.3 \%$ response percentage, $\sim 2.6$ shoots/node and $\sim 6.4$ roots/node (Deb et al. 2016). The success of the culm cuttings is the end-result of multiple factors that we need to address properly.

\section{Factors affecting culm cutting-based propagation}

Several internal and external factors are responsible for successful macropropagation with culm cuttings: age of mother plant (Saharia and Sen 1990); type of cutting (Singh et al. 2011); method of setting; type(s) and concentration of plant growth regulators (Singh et al. 2004); season (Singh et al. 2011; Chhetri and Kumar 2015); and substrate used for macropropagation (Gaintait et al. 2016; Ray and Ali 2016). In addition, environmental factors such as temperature (Senyanzobe et al. 2013), humidity, water balance, rooting medium, light intensity, wind speed, and pests and diseases, are also limiting factors for the macropropagation (Banik 1995). A summary of the findings of the previous literature on macropropagation through culm cuttings in different species of bamboo is provided in Table 1. The most important controllable critical factors are briefly discussed below.

Age of stock plants/cutting materials Limited literature is available on the age of stock plants to be used for culm cutting. Culms of $1-5$ years are better for many species, as reported by several authors. The use of culms of 1 year in B. balcooa (Joshi et al. 2012; Gaintait et al. 2016), 1.5 years in B. vulgaris (Bhol and Nayak 2012), 2 years in B. vulgaris (Hossain et al. 2006; Senyanzobe et al. 2013), Araundinaria alpine (Senyanzobe et al. 2013), Oxytenanthera abyssinica (Elbasheer and Raddad 2013), and 5 years in D. asper (Singh et al. 2004) as well as in B. vulgaris (Islam et al. 2011), have been reported as successful propagating materials for cutting-based vegetative propagation. Despite reports of success with culm cutting material of different ages in various bamboo species, juvenile culms are more suitable than older ones because of highly active buds that are critical for efficient propagation (Elbasheer and Raddad 2013). In general, 1-year-old culms are sufficient for culm cutting propagation (Bhatnagar 1974) but Saharia and Sen (1990) reported higher survival rates with 2-year-old culms than with 1- or 3-year-old culms in bamboo species like B. balcooa, B. pallida, B. bambos and Melocanna bambusoides.

Characteristics of culm cuttings Cutting-based propagation is suitable for many types of bamboo, but not cane bamboo species nor bamboo species that have a small or no hollow in the middle of the stem. The best culm cutting materials are generally obtained from the middle parts of the culm because of sufficient vigour for generation of roots and shoots. Lower sprouting from cuttings from the top region compared to those from the middle region has been reported by Bwanali et al. (2006). Ntirugulirwa et al. (2012) reported cuttings of the middle region had the highest number of sprouts (21.73) in comparison to the basal part (13.83) in 
Table 1 Summary of major findings to date on culm-cutting-based propagation of bamboo

\begin{tabular}{|c|c|c|c|}
\hline Bamboo species & Culm-cutting method details & Reference & Major findings \\
\hline \multirow[t]{2}{*}{ Arundinaria alpina } & Culm cutting method & $\begin{array}{l}\text { Ntirugulirwa } \\
\text { et al. (2012). }\end{array}$ & $\begin{array}{l}\text { Soaking in water is not effective for sprouting. Middle part of } \\
\text { culm most suitable for propagation. }\end{array}$ \\
\hline & One-nodal culm cutting method & $\begin{array}{l}\text { Senyanzobe } \\
\text { et al. (2013). }\end{array}$ & $\begin{array}{l}\text { Greenhouse in comparison to the polythene-shaded nursery } \\
\text { house gave better growth of propagating material. }\end{array}$ \\
\hline Bambusa bamboos & Two-nodal culm cutting, horizontal setting & $\begin{array}{l}\text { Saharia and } \\
\text { Sen (1990). }\end{array}$ & $\begin{array}{l}\text { Two-year-old culms have higher survival than other age groups } \\
\text { (one and } 3 \text { years). }\end{array}$ \\
\hline \multirow[t]{3}{*}{ Bambusabalcooa } & Two-nodal culm cutting, horizontal setting & $\begin{array}{l}\text { Saharia and } \\
\text { Sen (1990). }\end{array}$ & Two-year-old culms had higher survival than other age groups. \\
\hline & Culm cutting & $\begin{array}{l}\text { Joshi et al. } \\
\text { (2012). }\end{array}$ & $\begin{array}{l}\text { Two-year-old culm cuttings with intermittent misting gave best } \\
\text { response. Rooting per cent of culm cuttings set in different } \\
\text { seasons showed response as Spring (March) }>\text { Summer } \\
\text { (June) }>\text { Monsoon (August) > Autumn (October). }\end{array}$ \\
\hline & Two-nodal culm cutting, horizontal setting & $\begin{array}{l}\text { Ray and Ali } \\
\text { (2016). }\end{array}$ & $\begin{array}{l}\text { Coarse sand superior to either vermicompost or vermiculite for } \\
\text { the successful regeneration of bamboo. }\end{array}$ \\
\hline \multirow[t]{3}{*}{ B. nutans } & Culm cutting & $\begin{array}{l}\text { Stapleton } \\
\text { (1985). }\end{array}$ & $\begin{array}{l}\text { The reorientation of noded cuttings in bedding material } \\
\text { improved shooting and rooting percentage of cutting material. }\end{array}$ \\
\hline & $\begin{array}{l}\text { Single-node culm and culm-branch } \\
\text { cuttings, horizontal setting }\end{array}$ & $\begin{array}{l}\text { Singh et al. } \\
\text { (2011). }\end{array}$ & $\begin{array}{l}\text { Better rooting was recorded in culm cuttings ( } 88.3 \%) \text { compared } \\
\text { to branch cuttings }(46.6 \%) \text {, with the best rooting in the month } \\
\text { of May. }\end{array}$ \\
\hline & Culm cutting, 2-3 nodal, horizontal setting & $\begin{array}{l}\text { Gulabrao } \\
\text { et al. (2012). }\end{array}$ & $\begin{array}{l}\text { Cuttings collected in summer showed maximum sprouting and } \\
\text { rooting. }\end{array}$ \\
\hline \multirow[t]{2}{*}{ B. tulda } & $\begin{array}{l}\text { Culm cutting, 2-3 nodal, horizontal } \\
\text { planting }\end{array}$ & $\begin{array}{l}\text { Singh et al. } \\
(2011) \text {. }\end{array}$ & $\begin{array}{l}\text { Culm cuttings of B. tulda recorded adventitious rooting only in } \\
\text { May }(23.3 \%) \text {, and no root induction occurred in the culm-branch } \\
\text { cuttings. }\end{array}$ \\
\hline & $\begin{array}{l}\text { Culm cutting, 2-3 nodal, horizontal } \\
\text { planting }\end{array}$ & $\begin{array}{l}\text { Gulabrao } \\
\text { et al. (2012). }\end{array}$ & $\begin{array}{l}\text { Better rooting found in spring (46.67\%) than summer }(43.33 \%) \\
\text { and rainy season }(40 \%) \text {. }\end{array}$ \\
\hline \multirow[t]{2}{*}{ B. vulgaris } & Culm cutting & $\begin{array}{l}\text { Ntirugulirwa } \\
\text { et al. (2012). }\end{array}$ & $\begin{array}{l}\text { Middle part of culm is most suitable for propagation, and } \\
\text { soaking in water is not effective for sprouting. }\end{array}$ \\
\hline & $\begin{array}{l}\text { Culm cutting (1-, } 2 \text { - and 3-nodal segments); } \\
\text { setting orientation: horizontal, vertical and } \\
\text { slanting }\end{array}$ & $\begin{array}{l}\text { Bhol and } \\
\text { Nayak } \\
\text { (2012). }\end{array}$ & $\begin{array}{l}\text { Planting of 1- or 2-noded cuttings horizontally superior over } \\
\text { other alternatives for propagation. }\end{array}$ \\
\hline B. vulgaris & One-nodal culm cutting & $\begin{array}{l}\text { Senyanzobe } \\
\text { et al. (2013) }\end{array}$ & $\begin{array}{l}\text { Propagation of this species is effective in both of greenhouse } \\
\text { and polythene shaded nursery house. }\end{array}$ \\
\hline $\begin{array}{l}\text { Bambusa } \\
\text { Nagalandiana Naithani }\end{array}$ & Culm cutting and branch cutting & $\begin{array}{l}\text { Deb et al. } \\
\text { (2016). }\end{array}$ & $\begin{array}{l}\text { Rooting higher in culm cutting }(\sim 70.6 \%) \text { than in branch cutting } \\
(\sim 60.3 \%) \text { during summer season }\end{array}$ \\
\hline B. pallida & Two-nodal culm cutting, horizontal setting & $\begin{array}{l}\text { Saharia and } \\
\text { Sen (1990). }\end{array}$ & Two-year-old culms had higher survival than other age groups. \\
\hline Dendrocalamusasper & Two-nodal culm cutting & $\begin{array}{l}\text { Singh et al. } \\
\text { (2004). }\end{array}$ & $\begin{array}{l}\text { Culm cuttings better than branch cuttings in terms of sprouting } \\
\text { and rooting }\end{array}$ \\
\hline D. hamiltonii & Culm cutting, 2-3 nodal, horizontal setting & $\begin{array}{l}\text { Gulabrao } \\
\text { et al. (2012). }\end{array}$ & $\begin{array}{l}\text { Cuttings collected in summer season showed maximum } \\
\text { sprouting }(66.67 \%) \text { and rooting }(56.67 \%) .\end{array}$ \\
\hline D. giganteus & $\begin{array}{l}\text { Culm cutting, 2-3 nodal, horizontal } \\
\text { planting }\end{array}$ & $\begin{array}{l}\text { Gulabrao } \\
\text { et al. (2012) }\end{array}$ & $\begin{array}{l}\text { Maximum rooting found in spring }(73.33 \%) \text { compared with the } \\
\text { summer and rainy seasons (13.33\%). }\end{array}$ \\
\hline D. strictus & $\begin{array}{l}\text { Culm cutting, 2-3 nodal, horizontal } \\
\text { planting }\end{array}$ & $\begin{array}{l}\text { Gulabrao } \\
\text { et al. (2012). }\end{array}$ & $\begin{array}{l}\text { Cuttings collected in summer showed maximum sprouting (70\%) } \\
\text { and rooting (53.33\%) }\end{array}$ \\
\hline $\begin{array}{l}\text { Melocanna } \\
\text { bambusoides }\end{array}$ & Two-nodal culm cutting, horizontal setting & $\begin{array}{l}\text { Saharia and } \\
\text { Sen (1990). }\end{array}$ & $\begin{array}{l}\text { Two-year-old culms gave higher survival than 1-year or 3-year-old } \\
\text { culms. }\end{array}$ \\
\hline
\end{tabular}

Arundinaria alpine, and the figures in Bambusa vulgaris were 25.70 (middle part) and 17.37 (basal part). But the basal part of the culm, particularly for larger-diameter aerial culm-bearing nodes or buds, had the higher rooting capacity (Kigomo 2007). Number of nodes in each culm cutting is again important. Two- or one-nodal cutting was found better than whole-culm cuttings for high rooting and survival of B. blumeana (Cabanday 1957). Culm cuttings with one to three nodes have been reported in Bambusa balcooa, B. bambos, B. nutans, B. tulda, B. vulgaris, Dendrocalamus giganteus, D. hamiltonii, D. strictus and Araundinaria alpine by several workers (Singh et al. 2011; Gulabrao et al. 2012; Senyanzobe et al. 2013; Bhol and Parida 2015). Cutting-based propagation using culms with six nodes 
has been reported by Chhetri and Kumar (2015) for $B$. ventricosa. However, Bhol and Nayak (2012) reported high survival percentage for one- (93.33\%) and two(90\%) nodal culm cuttings in B. vulgaris. The one-node cutting method is the most promising for propagation because it is the most economical and easiest to handle. This method is recommended for raising planting stocks of the genera Bambusa, Dendrocalamus and Gigantochloa (Manipula et al. 1990; Ntirugulirwa et al. 2012).

During propagation, the orientation of cutting materials in bedding material is considered a critical factor to get optimum response (Medina et al. 1962). Horizontal setting $(98.89 \%)$ instead of vertical setting $(81.11 \%)$ was found more effective in terms of survival percentage for B. vulgaris (Bhol and Nayak 2012). Two-nodal culm cuttings from the basal and middle parts in Oxytenanthera abyssinica under horizontal setting gave high survival rate (Gebrehiwot et al. 2016). High survival rates with horizontal setting may be due to increase of surface area which is responsible for high water uptake from the surrounding medium (Stapleton 1985). Higher sprouting with horizontal setting was also reported by Chhetri and Kumar (2015) and Elbasheer and Raddad (2013) respectively for B. ventricosa and Oxytenanthera abyssinica.

Season Most studies on bamboo macropropagation have been restricted to the summer season for several bamboo species including Bambusa balcooa, B. pallida, B. bambos and Melocanna bambusoides (Saharia and Sen 1990), B. vulgaris (Bhol and Nayak 2012; Bhol and Parida 2015), D. asper (Singh et al. 2004) and B. nutans (Stapleton 1985). Singh et al. (2004) reported without addition of plant growth regulators, $98 \%$ rooting in culm cuttings of $D$. asper during summer. Better adventitious rooting $(88 \%)$ in summer was reported than winter (53.4\%) for B. nutans (Singh et al. 2011). Deb et al. (2016) reported that $\sim 70.6 \%$ of culm segments set during April responded positively, with $\sim 9.4$ sprouts/ node with $\sim 15.3$ roots/node within 6 months of setting; while setting during January gave $\sim 31 \%$ response of cutting materials with $\sim 3.1$ sprouts/node and $\sim 2.2$ roots/ node for $B$. nagalandiana. Gulabrao et al. (2012) observed that culm cuttings of B. bambos, B. vulgaris, $B$. balcooa, D. hamiltonii, B. tulda, D. strictus, D. giganteus, and $B$. nutans rooted best in spring (56.67\%), closely followed by summer $(54.58 \%)$, but less during winter (36.67\%).Thus, it is evident that the interaction between species and season is the most critical and summer is as the most suitable season for the majority of the species (Singh et al. 2006).

Plant growth regulators Plant growth regulators, mainly auxins, are widely used for bamboos species where rooting is difficult. The effect of growth regulators in bamboo is largely governed by the season and species. For example, B. vulgaris is easy to root and does not require growth regulator treatment. However, B. nutans, B. tulda, and D. asper require application of growth regulators. During spring, the endogenous level of hormones is often sufficient for root induction. Singh et al. (2006) reported that indole 3-acetic acid (IAA) in summer and indole-3butyric acid (IBA) in the rainy season were most effective for rooting in B. vulgaris and D. membranaceus. Seasonal dependency of growth regulator IBA was also reported by Singh et al. (2011) for B. tulda and $B$. nutans. Among the seasons, summer (88\%) was most effective in $B$. nutans (treated with $2 \mathrm{mM}$ IBA) in comparison to spring (60\%) and winter (21.8\%) with respect to survival. Different concentrations of IAA, IBA and $\alpha$-napthelene acetic acid (NAA) were used for culm cuttings of B. vulgaris by Bhol and Parida (2015) who suggested not using growth regulators for rooting as its endogenous hormones are sufficient for root induction. IBA is also reported as most effective for cutting-based propagation in several bamboo species (Islam et al. 2011, Singh et al. 2011, Gulabrao et al. 2012, Kaushal et al. 2011). However, presoaking with a high concentration of NAA for $24 \mathrm{~h}$ before setting was found to be superior during summer in B. ventricosa (Saad et al. 2016). The effect of growth regulators also depends on setting orientation of cutting materials. Horizontal setting of IBA-treated $D$. asper gave higher rooting (65\%) than that of under vertical position (55\%) during summer (Razvi et al. 2012).

Substrate materials for rooting The type of substrate (rooting medium) used in propagation beds for the establishment of the macropropagules is also important. This medium supports the plant pieces by fixing the cuttings in a particular position. Different types of rooting media: viz. fine sand (Gulabrao et al. 2012) for eight bamboo species; sand for $D$. asper (Singh et al. 2004) and Bambusa balcooa (Joshi et al. 2012); and loamy material (Stapleton 1985) for B. nutans, Dendrocalamus hamiltonii and D. hookeri, have been used for macropropagation of bamboo. Mixtures of coarse sand and gravel were reported in Bambusa nutans by Islam et al. (2011), sand to soil (1:1) for Araundinaria alpine and B. vulgaris by Senyanzobe et al. (2013). Several other substrates, namely different ratios of soil, sand and farmyard manure (FYM) for B. vulgaris (Razvi et al. 2011); soil for B. vulgaris (Bhol and Parida 2015), coarse sand mixed with fine gravel for B. vulgaris (Hossain et al. 2006); and coarse sand, soil, and sand plus soil and vermiculite for B. balcooa (Gaintait et al. 2016; Ray and Ali 2016) have 
also been reported to improve rooting in terms of increasing root number and root length. Sand has multiple advantages: it is inexpensive, having good drainage and aeration because of higher porosity enables oxygen to reach the developing rooting system, and maintains a relatively uniform temperature (Allaire et al. 2004; Baiyeri 2005; Shah et al. 2006; Amri 2010).

\section{Conclusions}

From the presented knowledge, "culm cuttings" could be the best regeneration option to meet the global need for bamboo planting stock. Rooting and sprouting, as well as survival of cuttings, depend strongly on the season, species and plant growth regulators used. To maximise the success rate, in the absence of prior knowledge of the propagation characteristics of a species, we suggest the following approach. Use culms with one to two nodes from the middle of mother stock plants that are 2- to 3-years old, and set horizontally in appropriate substrate, preferably sand, during summer and maintain proper humidity (80-90\%). Irrespective of age of plant, or growth regulator concentration, the best response was recorded in summer with winter being the worst. The available data are inadequate for deciding the best doses and duration of plant growth regulators (auxins) which again depend on season. So, doses and duration of auxins need to be standardised for different seasons and species. The interactions of species, auxins and seasons still need to be studied. Further research is also required on the selection of better growth-promoting substrates, to improve the potential of the culm-cutting method. It is worth mentioning that addition of biofertilizers like nitrogen fixers Azospirillum sp. or Phosphorous solubilising bacteria (PSB) to the growth medium was effective for macropropagation of banana (Sajith et al. 2014) and pomegranate (Damar et al. 2014) respectively. Addition of compost was also found effective for propagation of another woody plant, Litchichinensis (Kumar et al. 2014). To date, growth media were restricted to sand only in bamboo macropropagation. Others, like soil, biofertilisers, vermicompost, compost, vermiculite, and their possible combinations, are yet to be explored for improving rooting and survival rates of bamboo propagules. The cut ends of the cuttings are the entry sites of the pathogens causing several diseases. Research is needed for effective control of those infections which decrease the success rate in cutting-based propagation. Successful propagation under different agroclimatic zones is essential for wider acceptably. To date, no multi-locational trial of any cutting-based method has been reported. The immense potential of the cutting method must meet the demand, if a few more factors are addressed properly through future research.
Funding

Not applicable.

Authors' contributions

Md.NA conceived the idea, scrutinised and edited the manuscript. SSR surveyed the literature and drafted the manuscript. Both authors approved the final version of the manuscript prior to submission.

Competing interests

The authors declare that they have no competing interests.

\section{Publisher's Note}

Springer Nature remains neutral with regard to jurisdictional claims in published maps and institutional affiliations.

\section{Author details}

${ }^{1}$ IRDM Faculty Centre, Ramakrishna Mission Vivekananda University, Ramakrishna Mission Ashrama, Narendrapur, Kolkata, West Bengal 700103, India. ${ }^{2}$ Department of Agricultural Biotechnology, Faculty of Agriculture, Bidhan Chandra KrishiViswavidyalaya, Mohanpur, Nadia 741252, West Bengal, India.

Received: 13 June 2016 Accepted: 20 July 2017

Published online: 29 August 2017

\section{References}

Agnihotri, K. A., \& Nandi, K. S. (2009). In vitro shoot cut: A high frequency multiplication and rooting method in the bamboo Dendrocalamus hamiltonii. Biotechnology, 8, 259-263.

Ahlawat, SP, Haridasan, K, \& Hegde, SN (With inputs from Bhuyan, LR \& Singh, UV) (2002). Field manual for propagation of bamboo in north east India. Forest Research Institute, Department of Environment \& Forests, Government of Arunachal Pradesh.

Allaire, S., Caron, J., Menard, C., \& Dorais, M. (2004). Growing media varying in particle size and shape for greenhouse tomato. Acta Horticulturae, 644, 307-311.

Amri, E. (2010). Viable options and factors in consideration for low cost vegetative propagation of tropical trees. International Journal of Botany, 6(2), 186-193.

Arya, S., Satsangi, R., \& Arya, I. D. (2002). Rapid mass multiplication of edible bamboo Dendrocalamus asper. Journal of Sustainable Forestry, 4, 103-109.

Baiyeri, K. P. (2005). Response of Musa species to macropropagation: The effect of genotype, initiation and wearing media on sucker growth and quality in nursery. African Journal of Biotechnology, 4, 229-234.

Banik, R. L. (1984). Studies on the propagation techniques of different bamboo species of Bangladesh. In Paper presented in the workshop on the Contract Research Projects, Bangladesh Agriculture Research Council (BARC). 17-20 November. Dhaka.

Banik, R. (1985). Techniques of bamboo propagation with special reference to pre-rooted and pre-rhizomed branch cuttings and tissue culture. In A. R. Rao, G. Dhanrajan, C. B. Sastry (ed.), Recent Research on Bamboos (pp. 160-169). China: The Chinese Academy of Forestry, People's Republic of China and International Development Research Centre, Canada.

Banik, R. L. (1995). A manual for vegetative propagation of bamboos. INBAR technical report no. 6. Bangladesh: International Network for Bamboo and Rattan (INBAR) \& UNDP/FAO Regional Forest Tree Improvement Project (FORTIP) and Bangladesh Forest Research Institute (BFRI).

Bareja GB (2010). Bamboo Production and Propagation Methods. http://www. cropsreview.com/supportfiles/bambooproduction-and-propagationmethods. pdf. Accessed 20 July 2016.

Bhatnagar, H. P. (1974). Vegetative propagation rooting practices with forest trees in India. New Zealand Journal of Forestry Science, 4(2), 170-176.

Bhol, N., \& Nayak, H. (2012). Effect of planting alignment and cutting size on propagation of Bambusa vulgaris. Journal of Tree Sciences, 31(1\&2), 69-75.

Bhol, N., \& Parida, S. (2015). Influence of growth regulators on propagation of culm- and branch cuttings of Bambusa vulgaris. Journal of Tree Sciences, 34(1), 64-68.

Bwanali, R. J., Kayambazinthu, D., \& Namoto, M. (2006). Investigating the propagation techniques of Oxytenanthera abyssinica bamboo species in Malawi. Zomba: Forestry Research Institute of Malawi. 
Cabanday, A. C. (1957). Propagation of Kauayan-Tinik (Bambusa blumeana Schultz) by various methods of cutting and layerage. The Philippine Journal of Forestry, 13, 81-97.

Chhetri, S., \& Kumar, H. (2015). Effect of planting position on rhizogenesis in Buddha belly bamboo (Bambu saventricosa) under nursery condition. Journal of International Academic Research for Multidisciplinary, 2(12), 283-289.

Damar, D., Barholia, A. K., Lekhi, R., \& Haldar, A. (2014). Effect of growth regulators and biofertilizers on survival of pomegranate (Punica granatum L.) stem cuttings. Plant Archives, 14(1), 347-350.

Deb, C. R., Sangtam, T. L., \& Saku, N. S. (2016). Clonal macropropagation of Bambusa nagalandiana Naithani through culm segments and branch cutting: An endemic bamboo of Nagaland, India. Jamir International Journal of Conservation Science, 7(1), 147-154.

Dwivedi, A. P. (1988). Gregarious flowering in Dendrocalamus strictus in Shahdol (M.P.) some management considerations. Indian Forester, 114(9), 532-538.

Elbasheer, Y. H. A., \& Raddad, E. A. Y. (2013). Vegetative propagation of (Oxytenanthera abyssinica) by culm cuttings. Journal of Natural Resources and Environmental Studies, 1(3), 1-5.

Gaintait, S., Pramanik, B. R., \& Banerjee, M. (2016). Optimization of planting materials for large scale plantation of Bambusa balcooa Roxb.: Influence of propagation methods. Journal of the Saudi Society of Agricultural Sciences. http://dx.doi.org/10.1016/j.jssas.2015.11.008.

Gaur, R. C. (1985). Bamboo research in India. In A. R. Rao, G. Dhanrajan, \& C. B. Sastry (Eds.), Recent research on bamboos (pp. 26-30), China: The Chinese Academy of Forestry, People's Republic of China and International Development Research Centre, Canada.

Gebrehiwot, K., Woldetensae, T., Birhane, E., \& Tewolde-Berhan, S. (2016). Propagation potential of the lowland bamboo through seed and culm cuttings. Journal of Drylands, 6(2), 513-518.

Goyal, A. K., Middha, S. K., Usha, T., Chatterjee, S., Bothra, A. K., Nagaveni, M. B., \& Sen, A. (2010). Bamboo-infoline: A database for north Bengal Bamboo's. Bioinformation, 5(4), 184-185.

Gulabrao, A. Y., Kaushal, R., Tewari, K. S., Tomar, S. M. J., \& Chaturvedi, P. O. (2012). Seasonal effect on rooting behaviour of important bamboo species by culm cuttings. Journal of Forest Research, 23, 441-445 https://en.oxforddictionaries. com/definition/culm. Accessed 20 May 2017.

Hossain, M. A., Jewel, M. E. U., Sen, M., \& Serajuddoula, M. (2006). Rooting ability of Bambusa vulgaris var. striata branch cutting as influenced by cutting types and rooting hormones. Journal of Bamboo and Rattan, 5, 117-126.

Islam, M. S., Bhuiyan, M. K., Hossain, M. M., \& Hossain, M. A. (2011). Clonal propagation of Bambusa vulgaris by leafy branch cuttings. Journal of Forestry Research, 22(3), 387-392.

Joshi, R., Tewari, S. K., Kaushal, R., \& Tewari, L. (2012). Rooting behaviour of Bambusa balcooa Roxb. In relation to season, age and growing conditions. Indian Forester, 138(1), 79-83.

Kaushal, R., Gulabrao, Y. A., Tewari, S. K., Chaturvedi, S., \& Chaturvedi, O. P. (2011). Rooting behaviour and survival of bamboo species propagated through branch cutting. Indian Journal of Soil Conservation, 39(2), 171-175.

Kigomo, B. N. (2007). Guidelines for growing bamboo, KEFRI Guideline Series: No. 4 Nairobi: Kenya Forestry Research Institute.

Kumar, A., Pandet, S. D., Rai, R. R., \& Nath, V. (2014). Evaluation of alternate potting media mixtures for raising quality planting material of litchi in polybags. The Bioscans, 9(1), 381-384.

Mahapatra, R., \& Shrivastava, S. K. (2013, January). Bamboo rising. Down to Earth (pp. 24-32).

Manipula, B. M., Gianan, N. S., \& Virtucio, F. D. (1990). Survival and growth of culm cutting and whole culm of Gigantochloa atter as affected by age and culm portion. In Paper presented at the Second National Bamboo R \& D Symposium held at the ERDB auditorium, College, Laguna.

McClure, F. A. (1966). The bamboos: A fresh perspective. London: Harvard University Press.

Medina, J. C., Ciaramello, D., \& De P. Castro, G. A. (1962). Propagaçao vegetativa do bambu imperial (Bambuse vulgaris Schrad var vittata A. et C. Riv.) Bragantia (Boletin Tecnico do Institute Agrenomico de Sao Paulo), 21(37), 653-665.

Mehra, S. R., \& Mehra, L. K. (2007). Bamboo cultivation - potential and prospects. Technical Digest, 10, 26-31 https://www.nabard.org/pdf/BAMBOO.pdf Accessed 20 July 2016.

Mera, F. A. T., \& Xu, C. (2014). Plantation management and bamboo resource economics in China. Cienciay Tecnología, 7(1), 1-12.

Mishra, V. (2015). Bamboo and its connectivity to the different fields of economics: A potential resource of modern India. International Journal of Innovative Research \& Development, 4(2), 140-145.
Mudoi, D. K., Saikla, P. S., Goswami, A., Gogoi, A., Bora, D., \& Borthakur, M. (2013) Micropropagation of important bamboos: A review. African Journal of Biotechnology, 12, 2770-2785.

Ntirugulirwa, B., Asiimwe, T., Gapusi, J., Mutaganda, A., Nkuba, G., Ruzindana, N. A Ntabana, D., Barnabé, B., Kahia, J., \& Gahakwa, D. (2012). Influence of bud position on mother stem and soaking duration on sprouting of bamboo. Rwanda Journal, 28, 3-10.

Pathak, P. S. (1989). Bamboo resources in the world. Proc. seminar on Silviculture and management of bamboos (pp. 78-87). Jabalpur: Institute of Deciduous Forest.

Pattanaik, S., Das, P., Borah, E., \& Kaur, K. (2004). Vegetative multiplication of Bambusa balcooa Roxb. using branch cuttings. Journal of Bamboo and Rattan, 4, 365-374.

Phimmachanh, S., Ying, Z., \& Beckline, M. (2015). Bamboo resources utilization: A potential source of income to support rural livelihoods. Applied Ecology and Environmental Sciences, 3(6), 176-183.

Prabu, M.J. (2006). Bamboo cultivation: A viable alternative. The Hindu business line.

Ray, S. S., \& Ali, M. N. (2016). Evaluation of inexpensive bedding materials for culm cutting of Bambusa Balcooa Roxb. and its field performance. Journal of Biotechnology and Biomaterials, 6(2). doi:10.4172/2155-952X.1000227.

Razvi, S., Nautiyal, S., Bakshi, M., Bhat, J. A., \& Pala, N. A. (2011). Influence of season and phytohormoneson rooting behaviour of green bamboo by cuttings. International Journal of Conservation Science, 2(3), 199-206.

Razvi, S., Nautiyal, S., Bakshi, M., Bhat, J. A., \& Pala, N. A. (2011). Influence of season and phytohormones on rooting behaviour of green bamboo by cuttings. International Journal of Conservation Science, 9(3), 175-178.

Roy, S. S., Ali, M. N., Gantait, S., Chakraborty, S., \& Banerjee, M. (2014). Tissue culture and biochemical characterization of important bamboos. Research Journal of Agricultural Sciences, 5(2), 135-146.

Ruíz-Pérez, M., Belcher, B., Fu, M., \& Yang, X. (2004). Looking through the bamboo curtain: An analysis of the changing role of forest and farm income in rural livelihoods in China. International Forestry Review, 6(3-4), 306-316.

Saad, M., Kumar, H., \& Umrao, R. (2016). Effect of the different growth regulators on vegetative propagation of Buddha belly bamboo. Advances in Life Sciences, 5(4), 1310-1314.

Saharia, U. K., \& Sen, S. K. (1990). Optimum age of bamboo culms for nodal cuttings. Indian Forester, 116(10), 780-784.

Sajith, K. P., Uma, S., Saraswathi, M. S., Backiyarani, S., \& Durai, P. (2014). Macropropagation of banana - effect of bio-fertilizers and plant hormones. Indian Journal of Horticulture, 71, 299-305.

Seethalakshmi, K.K., \& Kumar, M.S.M. (Assisted by Pillai, K.S.K, \& Sarjam, N.). (1998). Bamboos of India: A compendium. Kerala Forest Research Institute and International Network for Bamboo and Rattan. Peechi and Beijing. 81-86247-25-4.

Senyanzobe, J. M. V., Jennifer, R., Grace, M., Faustin, N., Gaudence, M., \& Dieu, R. R. J. D. (2013). Growth of Bambusa vulgaris and Araundinaria alpina under different nursery site conditions at the higher institute of agriculture and animal husbandry, northern Rwanda. Journal of Biodiversity and Environmental Sciences, 3(9), 9-14.

Serajuddoula, M. (1985). Propagation of Bambusa vulgaris Schrad. and Melocanna baccifera Trin. by layering. In: Proceedings of 10th Annual Bangladesh Science Conference (pp. 79-80), Dhaka.

Shah, M., Mateen, K. A., \& Amin, N. (2006). Effects of different growing media on rooting of Ficus binnendijkii Amstel queen cutting. Research Journal of Agriculture and Biological Sciences, 1, 15-17.

Singh, S., Kumar, P., \& Ansari, S. A. (2004). A simple method for large scale production of Dendrocalamus asper. Scientia Horticulturae, 100, 251-255.

Singh, S., Nain, N. P. S., Nain, S. L., \& Tripathi, S. P. (2006). Patterns of adventitious root induction during different seasons in some bamboo species. Journal of Bamboo and Rattan, 5(1\&2), 101-107.

Singh, R. S., Singh, R., Kalia, S., Dalal, S., Dhawan, K. A., \& Kalia, K. R. (2013). Limitations, progress and prospects of application of biotechnological tools in improvement of bamboo: A plant with extraordinary qualities. Physiology and Molecular Biology of Plants, 19, 21-41.

Singh, S., Yadav, S., Patel, P. K., \& Ansari, S. A. (2011). Adventitious rhizogenesis in Bambusa nutans and Bambusa tulda: Influence of seasonal variation, IBA and cutting type. Journal of Forestry Research, 22(4), 693-696.

Stapleton, C. M. A. (1985). Studies on vegetative propagation of Bambusa and Dendrocalamus species by culm cuttings. In: A.N. Rao, G. Dhanarajan, C.B. Sastry (Eds.), Recent Research on Bamboos (pp.146-153). China: The Chinese Academy of Forestry, People's Republic of China and International Development Research Centre, Canada. 
Subramaniam, K. N. (1998). Bamboo genetic resources in India. In K. Vivekanandan, A. N. Rao, \& V. R. Rao (Eds.), Bamboo and rattan genetic resources in certain Asian countries (pp. 33-63). Serdang: IPGRI-APO. Yeasmin, L., Ali, M. N., Gantait, S., \& Chakraborty, S. (2015). Bamboo: An overview on its genetic diversity and characterization. 3 Biotech, 5, 1-11.

Yengkopam, R. D. (2013). Bamboo forest resources of India and its role in food security- a review. Agriculture Review, 34(3), 236-241.

Yuming, Y., Kanglin, W., Shengji, P., \& Jiming, H. (2004). Bamboo diversity and traditional uses in Yunnan, China. Mountain Research and Development, 24(2), 157-165

\section{Submit your manuscript to a SpringerOpen ${ }^{\circ}$ journal and benefit from:}

- Convenient online submission

- Rigorous peer review

- Open access: articles freely available online

- High visibility within the field

- Retaining the copyright to your article

Submit your next manuscript at $>$ springeropen.com 